\title{
Sacco's Strategies and Member's Savings in Deposit Taking Saccos in Nairobi County- Kenya
}

\author{
Patrick Chege Kariri $^{1}$, Dr. Lucy Kavinda ${ }^{2}$ \\ ${ }^{1}$ School of Business, Kenyatta University, Kenya \\ ${ }^{2}$ Department of Accounting and Finance, Kenyatta University
}

\begin{abstract}
Just like the case with all investments and other firms, Savings and Credit Co-operative Societies (SACCOS) in Kenya are investment with the target of maximizing their wealth. It is that wealth maximization and capital accumulation is a critical objective whenever SACCOs have chosen pushes for more savings from members. The purpose of the study was to conduct an effect analysis of savings and credit co-operative societies strategies on member's savings in Sacco's' (Nairobi county- Kenya). Specifically, the study focused on the following research objectives; to establish the relationship between loan policies, member training and customer relationship management strategy on member's savings in Sacco's in Nairobi County. The study targeted the forty two licensed savings and credit co-operative societies in Nairobi County-Kenya. Specifically the study targeted the management of the Sacco's, and clients of savings and credit co-operative societies in Nairobi County-Kenya. From the projected target population which was about 12,212 respondents. A purposive sampling technique was employed in this study. Then, simple random sampling procedure was then used to select about $50 \%$ of the Sacco's management/staff targeted from the target population. Then purposively again a random sampling technique was employed to select at least two Sacco's clients at each office visited from the 42 registered Sacco's in Nairobi County. In analysis, Descriptive and inferential statistics were considered to conduct an analysis of data generated from respondents. The information obtained was presented through frequency distributions tables, evidence of percentages and the researcher categorized variables. The study found that loan policies, member training and customer relationship management strategy positively and significantly affected member's savings. The study concluded that it is a SACCO policy to appraise loans based on members' savings and ability to repay. However, a member needs to clear any outstanding emergency loan, if any, before applying for another. Training of members both employees and clients leads to increased job satisfaction and morale among employees, motivation, increased efficiencies in processes, resulting in financial gain, increased capacity to adopt new technologies and methods by clients, increased innovation in strategies and products and enhanced company image. Customer relationship management strategy enhances better customer service, CRM systems are useful in identifying potential customers, CRM data ensures effective co-ordination of marketing campaigns. The study recommended that loan policy should clearly communicate the strategic goals and objectives of the SACCO, as well as define the types of loan exposures acceptable to the institution, loan approval authority, loan limits, loan underwriting criteria, and several other guidelines. SACCO should train members on communications; because the increasing diversity of today's workforce brings a wide variety of languages and customs. Customer service; because increased competition in today's global marketplace makes it critical that employees understand and meet the needs of customers. Customer relationship strategy should aim at governing how to satisfy customers beyond developing good products and services, help retain existing customers to maximize efficiencies and reduce the cost of acquisition and ensure customer satisfaction and a memorable brand experience.
\end{abstract}


Key Words: Sacco's Strategies, Loan Policies, Members Training, Customer Relationship Management, Deposit Taking Saccos

DOI: $10.35942 /$ ijcab.v3iV.71

\section{Cite this Article:}

Kariri, P., \& Kavinda, L. (2019). Sacco's Strategies and Member's Savings in Deposit Taking Saccos in Nairobi County- Kenya. International Journal of Current Aspects, 3(V), 210-226. https://doi.org/10.35942/ijcab.v3iV.71

\section{Introduction}

Accessing finance for investments and meeting daily needs or during emergencies has been a challenge for many Kenyans (Oloo et al., 2014). To address this, Kenyans have formed financial co-operatives through which they save jointly in a common pool from which they in turn access funds to meet their short and long-term investments needs. The most common financial co-operatives in Kenya include Savings and Credit Co-operatives (SACCOs), Housing Co-operatives, Insurance Co-operatives and Investments Co-operatives. According to Sacco Societies Regulatory Authority (2016) the role of SACCOs has been critical in savings mobilization in Kenya, accounting for over $48 \%$ of national Savings (IMF World Economic Outlook, April 2014). The Financial Sector Reform and Development Strategy, and the Government Vision 2030 stress the requirement for improving money related administration conveyance in the area through the help for SACCOs so as to guarantee fulfillment of budgetary access and consideration. Sacco's in continent Africa are purposed to supply an alternate to up the fascinating state of affairs in low financial gain countries. SACCOs are group of people membership based mostly monetary establishments that are shaped and held by their members in championing of their members economic interests. It may also contribute positively to Human Integrated Development (Jagongo et al., 2013).

According to SASRA, (2016) Sacco's in Kenya is currently embracing new methods in innovation and product improvement. The Sacco's are focused in assembling savings from the members to take care of his or her credit wants. Additionally, thereto from the members to cater for his or her credit wants. Additionally thereto the Sacco's are stepping into cooperative banking ordinarily named as FOSA. This can be a fundamental shift from the common follow among Sacco's wherever they solely offered BOSA wherever credit granted to members would solely be paid at business. In today's trade environment with fixed margins and intense competition, the client expertise is a critical determinant for the success of a business. Thanks to this realization, Sacco's should embrace the client relationship centered culture as an example to achieve a competitive edge. Generally, Sacco's should take into account its specific scenario and its members' wants and expectations. This can successfully facilitate improve member retention, improve product and establish people who are most profitable to members (Co-operative Development Policy report 2017).

\subsection{Member Savings Culture in SACCOs' in Kenya}

In Kenya, developing a savings mobilization culture in Sacco's is executed by varying the main focus and adjusting of behavior as a result of savings could be a culture, a behavior and some way of life (Kimani, 2015). By and large, industrial culture may aid in growth of wealth. According to Sacco Societies Regulatory Authority (2016) gasping savings culture involves the destruction of recent and good for nothing in-built behavior and principles, and therefore the assimilation of recent ones. this is often a commitment toward the participation during this socioeconomic revolution caused by Sacco's by saving often a minimum of fifth of one's remuneration, or different gain into a Sacco so by the synergy of 
numbers, the assembling of savings mobilization created can be a supply of lowcost credit bonded solely by the members of the Sacco.

In championing of a savings mobilization culture, the decrease of consumption trends and reliance on simple to acquire loans ought to be depressed by sensitizing campaigns to assist amendment the culture of expenditure on gratuitous merchandise, and learning the way to manufacture a number of the essential things like vegetables, fruits and maize and rice (Manyara, 2013). The Co-Operative Development Policy report (2017), reported that, a culture of savings must be inculcated amongst all young and previous folks. The place to begin is in institutions wherever a cooperative syllabus ought to be developed and educated in the slightest degree levels of the college system. The formation of Savings and Credit Cooperatives all told work places ought to be created obligatory, whereas encouraging the development of savings clubs in academic establishments. According to SASRA, (2014) Change of way of thinking/feeling and dependence syndrome, associate degree angle of dependence ought to be discouraged within the society in order that people will mobilize themselves and manufacture merchandise and services or people will move, work along and save. This may be done by denitrifying opinion leaders within the country and allow them to move outside the country to work out what the opposite individuals have finished themselves.

\subsection{Sacco's Strategies and Members Savings}

Nowadays the business environment is characterized by close margins and intense competition making client specialization a key determinant as to whether corporations are going to be palmy or not (Oloo et al., 2014). Grounded on this revelation, Sacco's should embrace the client relationship centered culture to achieve a competitive edge. Sacco's should contemplate its specific scenario and its members' wants and expectations. this may successively facilitate improve retention of members, improve merchandise and determine people who are most profitable to member (Sacco Societies Regulatory Authority, 2016). According to SASRA, (2016) key Sacco's strategies in wining deposits include; customer association management, coaching and education, info technology, regulative frame work, mentorship and analysis, monitoring, building up an investment funds culture, advancing of a reserve funds activation culture, change of point and reliance issue, subsidizing of eccentric cooperatives, adequate institutional help arrangement and capacity working inside the agreeable development; customer relationship the board is that the logic, approach related planning technique interfacing very surprising players inside and to synchronize their endeavors in making a general profitable grouping of encounters, item and administrations for the customers.

KUSCCO, (2016) argues that, one of the continuing challenges Sacco's face, is in optimizing client satisfaction and developing client Relationship Management. So as to lift client satisfaction levels Sacco's should invest in choosing the right those who not solely have the useful, technical competency however even have the correct perspective. They also proposed that, Sacco's should ceaselessly develop, inspire and manage its staff to make client relationship culture that depends on technical and social skill. Sacco's should invest in establishing economical service delivery processes and procedures that seem clear to the client and improve on client interaction with the Sacco. Sacco's should incorporate continuous improvement in commission delivery particularly once things fail by lease the numbers comprehend such things ahead or timely. Sacco Societies Regulatory Authority, (2016) argue that, trust is a vital part in building client relationship and intrinsically honesty goes on method. Whereas a Sacco could have legitimate motivations to with hold unsafe news, its esteem taking note of that a deferral or contortion will do much more mischief to a relationship than perilous news immediately 
found. Criticism is another important part in keeping up brilliant clients' relations with individuals as this aide in up administration conveyance. Representatives should be prepared to deal with individuals' protests adequately by utilizing the best possible blend of individual inclination, statement of regret and assurance. In order to convey extraordinary administrations, it's fundamental to make a customer relationship focused on culture.

KUSCCO, (2016) additionally discovered that, education could be a core strategy and campaigns must direct at serving to folks to know the importance of savings mobilizations. As a lot of folks go in paying employment, families begin to own extra money which will be directed towards savings. Training and education in forms an integral half within the promotion of the union services and relevant problems within the management of Sacco's. Firm growth strategies are justified by Porter (1980) who advised that, having a growth strategy make it possible for a firm to achieve a sustainable position in its market of operation. Consequently, there are many growth strategies that a firm can adopt to grow and expand its operations albeit not every growth strategy is appropriate for every business. The Sacco industry is unique since success relies heavily in deposits by members hence growth strategies focuses on members' saving mobilization. According to Oloo et al., (2014) ICT and loan policies are key strategy lines to adopt. He further suggested that market development and members training have done well for most Kenyan Sacco's as well. Thus the current study attempts to unpack the association between loan policies, members training and customer relationship management as independent variables for Sacco strategies in saving mobilization.

\subsection{Sacco's Industry Analysis in Kenya}

The SACCO'S in the republic of Kenya subsector is taken considered the quickest growing within the cooperative movement. Sacco's in the republic of Kenya have speedily grownup to be the biggest in Africa, accounting for sixty, 64, and sixty three per cent of the continent's assets, loan and analysis severally. Six percent providing deposit taking services usually referred as Front workplace Services Activity (KUSCCO, 2016). Sacco's in Republic of Kenya have chop-chop full-grown to be the biggest in Africa, accounting for sixty, 64, and sixty three per cent of the continent's savings, loan and assets, severally. Six percentage giving deposit taking services unremarkably referred as Front workplace services activity (SASRA, 2016). With changes that at some stage saw utilization of Sacco's drop from thirteen percent in 2006 to nine percent in 2009 gratitude to solid challenge from banks and option money related foundations, and elective variables like declining participation on account of conservation and passing's, Sacco's were compelled to return up with ways and stock to enable them to manage these difficulties (KUSCCO, 2016). Some of these procedures including the regularly changing tenets of enrollment and creating with a substitution fluctuate of stock. Sacco loan defaulters are placed on notice when the sub-sector's regulator, nihilist Societies regulatory agency (SASRA) same it's currently given Sacco's the inexperienced lightweight to start out mark out offenders and forward their names with Credit Reference Bureaus (CRBs).

The loan defaulters will be banned from Sacco's, furthermore it will also make it extremely difficult to access loans for them from other financial institutions for instance the commercial banks, Higher Education Loans Board and micro-finance institutions. Societies regulatory agency has also warned Sacco's to be cautious of members who are out to acquire loans with the intention of not repaying them, even though they are in a position to pay off their debt obligations (Kioko, 2014). According to SASRA, (2016) when evaluating the potential borrowers, priority should also be given to the personality of an individual. In other words, the character of a potential member is overrides the ability to repay the loan. The current 
move is part of Sacco movement efforts to eliminate loan defaulters from the industry and to ascertain that; Sacco's have sufficient funds for on-lending. The most critical challenge SASRA has to deal with is the non performance of the loan portfolio. Approximately 80 per cent of the assets of the Sacco involve loans to members.

\section{Problem Statement}

The SACCO movement especially in Kenya has for an along time performed underneath the individuals desires accordingly perpetrating discontent among the greater part of their individuals (WOCCU, 2014). As indicated by SASRA (2016), notwithstanding coordinated endeavors, Kenya has been unfit to achieve the ideal dimensions of reserve funds as pondered in the Kenya Vision 2030 which is viewed as satisfactory to back wanted dimensions of ventures. Reserve funds, as a proportion to GDP, diminished from 14.4\% in 2008 to a low of $11.9 \%$ in 2012 , contrary to the focused on $16.2 \%$ and $27.7 \%$ appropriately. In any case, the segment of ventures of the country's GDP has stagnated at around $20 \%$, against the focused on $23.2 \%$ and $32.6 \%$ amid a similar period as needs be. This low investment funds culture has contributed altogether to the low capital base of many Sacco's in Kenya. In Kenya, The Ministry of Cooperative Development and selling through the cooperative movement concurs that the saving culture in the African nation Kenya is not fully developed and one thing must be done, considering that, the govt. of African nation through the cooperative movement is however to return up with policies to encourage savings over the years (Sacco Societies Regulatory Authority, 2016). According to WOCCU, (2014) Sacco's raise savings from and make loans to members from which revenue is generated and that, Sacco Societies goal is member empowerment through mobilization of savings, advancement of credit and ensuring Sacco's' extended, sustainability through well advised financial practice.

According to Deji, (2013), Sacco's particularly in Republic of Kenya, are making an attempt to deal with members' peremptory request by funds mobilization and advancement of credit to members. Nevertheless, they need not been ready to increase their wealth adequately through accumulation of sufficient institutional capital to provide funding for nonwithdrawable capital funded assets, give cushion to soak up losses and impairment of members' savings. From the existing literature, most studies have addressed issues around the overall Sacco's credit policies and management and the relationship they share with the financial performance for instance (Kaloi, 2014). The past studies relating to Sacco strategies and members savings, they have not adequately addressed the specific Sacco's strategies aspects discussed in this study but rather have concentrated on financial stewardship and growth aspects for instance (Olando, Mbewa and Jagongo, 2013). Moreover, there exist conflicting findings on the importance of members' savings mobilization and the relationship this share with Sacco's strategies employed. For instance; Kioko, (2014) established that, with the intense competition within the financial industry, especially from banks who do not necessarily require savings to advance loans. The saving mobilization endeavor by SACCOs is obsolete. However, several studies are pro the savings culture for instance, Mutembei et al., (2017) who proposed that SACCOs need to embrace the savings mobilization endeavors to remain relevant and viable. In recognizing the significance of members' savings mobilization for the development of a Sacco, the study will determine the relationship between strategies adopted by Sacco strategies and member savings in Sacco's (Nairobi county- Kenya).

\section{Research Objectives}

The researcher proposed to establish the relationship between deposit taking SACCOs strategies and member's savings in Sacco's (Nairobi County- Kenya) 
The specific objectives were:

i. To establish the relationship between loan policies and member's savings in deposit taking Sacco's in Nairobi County.

ii. To determine the influence of members training on member's savings in deposit taking Sacco's in Nairobi county.

iii. To determine the relationship between customer relationship management strategy and member's savings in deposit taking Sacco's in Nairobi county.

\section{Review of Theories}

Existing literature highlights a number of theories with regards to Sacco's' Strategies and Member's Savings. The study reviews: The Market-Based View (MBV), The KnowledgeBased Theory and The Capability-Based View (RBV) Model.

\subsection{The Market-Based View (MBV)}

The Market-Based Theory (MBV) of procedure suggests that exchange elements and outer market introduction are the main determinants of firm execution (Peteraf and Bergen 2003; and Porter, 1996). They highlighted that, the sources worth a great deal of money for the organization are firmly fixed within the focused circumstance describing its finished result key position. The strategic spot may be an organization's unique set of actions that are completely dissimilar from their rivals. The Market-Based View (MBV) incorporates the situating workforce of hypotheses of methodology and speculations created inside the modern association financial science part (Porter, 1996). Throughout this part, the primary spotlight was on the company's environment and outside components. They saw procedure inside the setting of the business as a full and in this way the situation of the firm inside the market similarly to its rivals. Porter, (1996) clarified why firms must propel system in response to the structure of the exchange amid which the organizations contends in order to acknowledge focused favors. In planning procedure, companies conventionally fabricate partner degree when all is said in done evaluation of their own upper hand by means of partner degree appraisal of the outside climate bolstered the 5 powers model. The 5 forces into thought convey with it the accompanying: hindrances to section, risk of substitutes, talk's capacity of providers, talk's capacity of supporters and rivalry among contenders. In this circumstance, an undertaking wellspring of market control puts forth a defense for its relative execution. The relevance of the Market-Based View (MBV) to the study resides on the firms' need to scan and manage best its environment and external factors which in this case are level of members' income and regulatory framework since, Market-Based View theory asserts that industry circumstances and external market point of reference are the primary impetus of firm performance.

\subsection{The Knowledge-Based Theory}

The Knowledge-Based view has unique characteristics which distinguishes it as the most imperative and significant recourse. Hamel and Prahalad (1994) proposed that knowledge, intellectual assets, know-how and skills are the real determinants to predominant execution in the information age. Nowadays, several researchers have preferred the Knowledge-Based to Resource-Based for instance; Evans (2013) suggesting that data is that the most vital resource of a firm. He distinguished that material resources decrease once employed in the firm, whereas data assets increase with use. Moreover, Tiwana (2012) highlighted that capital, technology, market share or product sources are easier to repeat by alternative companies whereas data is that the solely resource that's tough to imitate. According to Grant (1996) there are two varieties of knowledge: knowledge information and ability and divides structure 
knowledge into 3 categories: advanced knowledge, core knowledge, and innovative knowledge. Core knowledge is the fundamental learning that allows a firm to get by inside the market inside the short-run. Propelled information makes accessible for utilize the association with practically identical learning as its adversaries and licenses the firm to effectively total inside the present moment. Advancement learning gives the firm its aggressive position over its adversaries. The relevance of the theory to the study, resides on customer relationship management strategy which requires both advanced knowledge and innovative knowledge management in relation to customer satisfaction. Zack, (1999) observed that, those firms with innovative knowledge are able to introduce innovative services or products, potentially helping them become market leaders.

\subsection{The Capability-Based View (RBV) Model}

A capability is defined as an organization capacity to set up resources, typically in combination using organizational processes, and influence a desired end (Teece et al., 2007). They are data based, impalpable or substantial procedures that are explicit to a firm and created after some time through confused cooperations among the company's assets'. Give (1996) characterizes an organization capacity as, 'an association's capacity to perform again and again a beneficial errand that relates either legitimately or in a roundabout way to a company's ability for making worth through impacting the handling of contributions to yields'. Grant, (1996) conjointly partitioned capacity into four classifications to be specific: action related abilities, cross-utilitarian abilities, wide useful capacities and particular capacities. Grant, (1991) contended that upper hand is sourced from the capacities while assets are the wellspring of abilities. He further recommended that assets don't make up the continued upper hands for an association, while its capacities do. Right now scientist, for example, Haas and Hansen, (2015), have upheld the hugeness of capacities and suggested that an association can accomplish upper hand from its capacity to apply its abilities to perform imperative exercises inside the association. Sirmon et al., (2013) emphasized the significance of organization learning. They counsel that capabilities and organization learning implicitly and expressly are a component of any strategy inside a firm. It's been proposed by (Zack, 1999) that the flexibility to find out and build new information is important for gaining competitive advantage.

In application, The Capability-Based View (RBV) Model highlights on the need for distinctive capabilities which allow companies to review their competitors over time and sustain competitive advantage, the resulting in widening market shares and improved profit margins which in this case is more savings. The pedestal of the capability lies in knowledge, skill, and expertise of employees in the firm which in this case allow for superior loan policies. According to Sirmon et al., (2013) in order to beat competitors and maintain a competitive advantage, the company is required to have a distinctive capability.

\section{Empirical Review}

In this section, the study addresses the various aspects of the research objectives in relation to past studies. The research work compares and contrast different authors' views on the relationship between Sacco's strategies and member's savings in deposit taking Sacco's.

\subsection{Loan Policies and Members' Savings}

Loan analysis being the primary step in loan process, should be done consistent with the set down rules and laws (Co-Operative Development Policy report 2017). The issues of an efficient analysis embody eligibility to application and ranking. Non eligible applications would occasion losses caused by failure to recover the loan since a number of the 
lonees don't have capability to repay the borrowed funds lack adequate security (Maina, 2015).

As indicated by Kimani, (2015) inability to rank the application proposes that absence of affirmation on once partner degree somebody would hope to incite a credit that outcomes in individuals' uneasiness and loss of trust. In the end, subsequently, the individuals discover one self-lessening their offer offering or/and endeavoring to discover for advance advances from elective sources. This decreases the obtaining comparatively in light of the fact that the capital base and subsequently piercing the Sacco's' riches. Kinuthia (2014) contended that, viable decisions on advance dispensing impact the development capability of Sacco's' riches though ineffectual decisions debilitate the acquiring capacity. He stressed that, the indications of those loan disbursement choices embody, the potency of investment, that is the quantitative relation of loan portfolio to the whole assets. This is often wherever associate degree practical advance payment develops the advance portfolio that will be that the center speculation that outcomes in development of Sacco's' riches. Another marker is that the Loan Penetration Rate (LPR) that will be that the credit inclusion quantitative connection. the upper the infiltration rate, the upper the arrangement of credits therefore fulfillment of individuals. A high entrance rate is an indication of unfurl of hazard and along these lines decrease of misconduct rate and diminished misfortunes (Kinuthia, 2014).

A Sacco may be a Co-operative Society, whose agenda is to give support to its members to avoid wasting, thereby making or accumulating capital, that is then on lend to the members at an inexpensive rate of interest (Co-Operative Development Policy report 2017). A Sacco accords members a chance for saving often, assembling the savings and thereby making a pool from that they borrow completely for productive functions at truthful and affordable rates of interest than would be obtained in alternative financial establishments'. According to Kinuthia, (2014) the foremost effective strategy for promoting additional rise within the saving behavior in society is to support monetary deepening so as to boost monetary mediation, which given the very fact that monetary institutions' coverage of the urban areas is comparatively enough, reaching to the agricultural areas specifically by formal establishments is proscribed. there's would like for making certain that the maximum amount as, efforts are current to encourage rural reaching by the formal banks, there's nice would like for the socio-economic and set-ups within the rural areas to be mirrored within the monetary services.

Maina, (2015) contends that, loan good administration should embrace the reduction of costs, while at the indistinguishable time, rising its blend monetary profit through the presentation of a great deal of part amicable stock and strategies. Expanding premium wages by making ways that to get to a great deal of assets to loan to inventive individuals while not depending on outside getting and widening its transfer parameters with some to advancing individuals monetary welfare and figuring a ton of ideal with elective cash mediators; managing instances of misapplication of assets, a standard drawback that part wherever are mindful of (Main, 2009). Co-Operative Development Policy Report (2017) recommended that, Sacco's should defeat the low part certainty occasioned by low desires for accomplishing capital additions from their reserve funds, high aggressive from banks and diverse financial foundations, and low specialized capacity. Board of trustees individuals to know and welcome the imperative speculation openings possible that may debase the ability to investigate realistic business possibilities that may serve individuals needs a great deal of agreeable of these can energize numerous a part on amassing very least offers at FOSA and would conjointly result in increment of riches insofar as there is no misfortune in premium and the vital. The last pointer of advance dispensing is body intensity. 


\subsection{Member Training/Education and Member's Savings}

A properly driven membership will certainly work and reap most advantages if the FOSA funds mobilization program was executed professionally in an exceedingly clear and and responsible manner, and are absolutely wise concerning the surrounding atmosphere. This can be as a result of with FOSA, the society offers several merchandise to its members that have extensive important on increasing the degree of members' deposits, enhancing profitableness, growth and therefore improvement of the reform on the shareholder's investments and also the overall liquidity position to a lot of cheap levels (KUSCCO, 2016). In attempt to increase the efficiency, Manyara (2013) suggested that, Sacco's should give item like low value wage advance to individuals, wage process, safe authority administrations for records and Check grouping all together that the general public and in this way the general enrollment will extravagant diminished charge and commissions, low least record adjusts, improved liquidity and capacity to loan and get and cut back dependence on shylocks and diverse cash transgressors. According to Kinuthia, (2014) training would, improve cooperation that ensures there exists amongst Sacco members as a feeling of identity, cooperation, mutual concern loyalty and trust. The cooperation protects the Sacco as a result of members apprehend one another. This facilitates potency and effectiveness in credit management for the expansion of business enterprise and higher access to social services like medical and education simply to say some. Members are the center and are reasons for the Sacco existence. They additionally argued that Sacco's should unceasingly develop, inspire and manage its staff to make client relationship culture that depends on technical and social skills.

\subsection{Customer Relationship Management Strategy and Member's Savings}

Client relationship management may be referred to as a series of methods and processes that make new and mutual worth for individual customers, builds preference for his or her organizations and improves business results over a period of association with their customers (Barney, 2015). Deji, (2013) argues that, this platform gives a firm focus on producing the only asset of the firm that is critical in the long term, radically deeper relationships with prized customers. Ofei, (2014) contends that, for a firm to increase customer satisfaction levels Sacco's shall put emphasis in investing in selecting the correct people who have the functional, technical competence and have the right attitude too. Past researches have revealed that attitude is the most significant requirement functional expertise and skill there is. According to Champo et al., (2014) Sacco's should invest in establishing economical service delivery processes and procedures that seem clear to the client and improve on client interaction with the Sacco. Sacco's should incorporate continuous improvement in commission delivery particularly once things get it wrong by wrong by allowing the members realize such things earlier or timely. Trust is a crucial part in building client relationship and intrinsically honesty goes on method whereas a Sacco could have valid reasons to withhold unhealthy news, it's price noting that a delay or distortion will do rather more injury to a relationship than unhealthy news quickly discovered.

\section{Conceptual Framework}

Conceptual framework is outlined as a part of the research project method within which a particular idea is outlined as a measurable incidence or in measurable terms that essentially provides a transparent that means of the idea (Cooper and Schindler, 2010). in line with Mugenda and Mugenda (2003), a abstract framework may be a diagrammatical presentation of the connection between dependent and independent variables. The abstract structure of the study will incorporate both the independent variables and the variables as shown below: 
Independent Variables

\section{Dependent Variable}

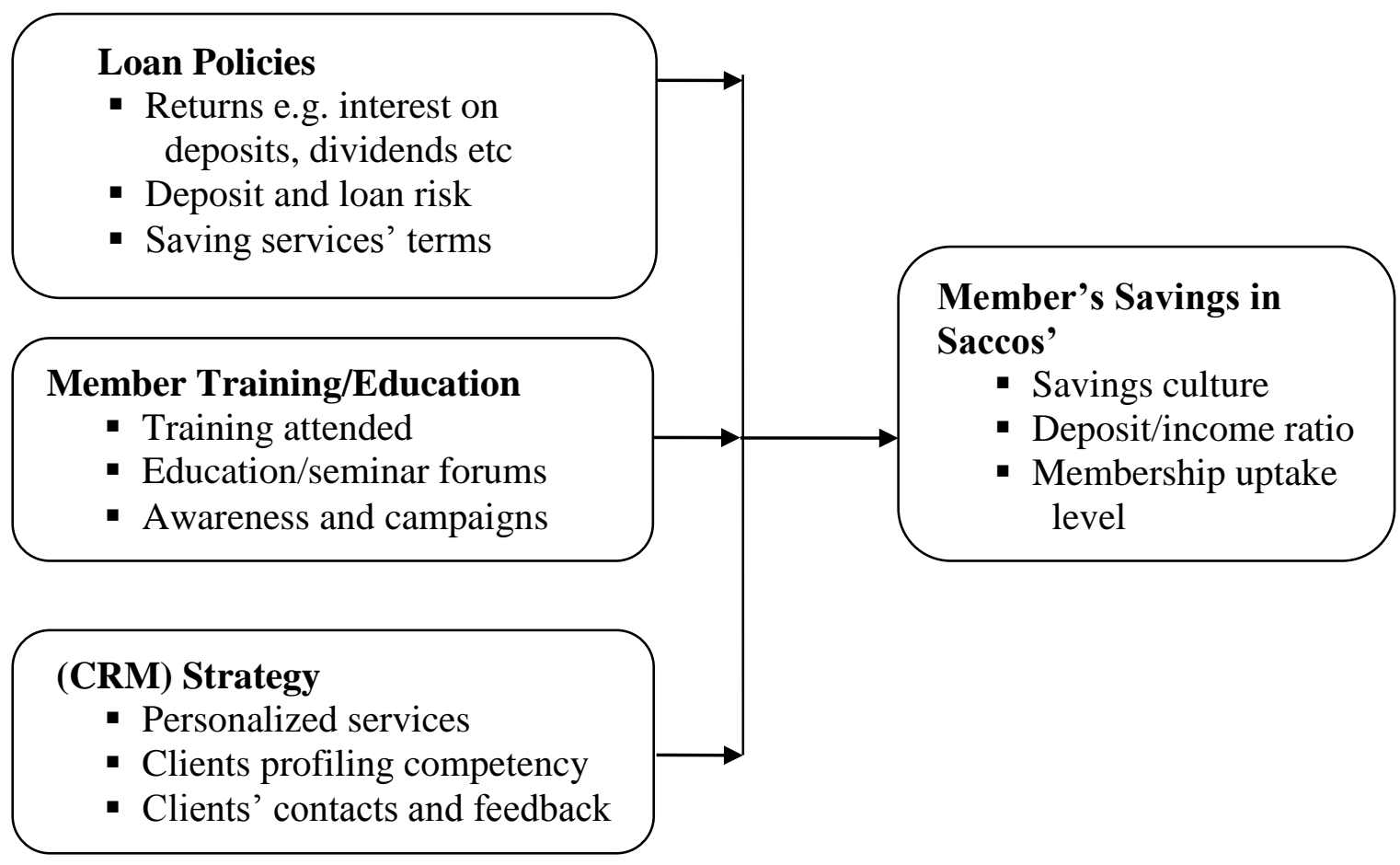

Figure 1: Conceptual Framework

\section{Source: Researcher (2018)}

Under conceptual framework variables the research looks at deferent meanings of variables that the researcher made as basis for understanding the concept for which the selected variables were used. In this research work, loan policies are those guidelines which give authority, regulations and structure to administer the loan portfolio effectively, regulates lending risk and ensures the enterprise soundness and stability. In this case the activities of the Sacco with regards to loan administration which relates to members' savings in the Sacco's. In this study Customer relationship management (CRM) is used to refer to practices, strategies and technologies that in this case Sacco's utilize to analyze customer interactions and manage data throughout the lifecycle of the customer with the objective of enhancing trade relationships with customers, aiding in customer retention and increasing sales growth. In this research work, training relates to impacting knowledge to others or oneself, any skills and knowledge that addresses specific useful competencies. In the Sacco's members training has specific goals that are: improving members' capability, capacity, productivity and understanding of the Sacco operations so as to benefit from the services and products offered.

\section{Methodology}

The study aimed at collecting data from all the forty two licensed Sacco's in Nairobi CountyKenya. Specifically, the study targeted the management of the Sacco's, in Nairobi CountyKenya. The research adopted an explanatory survey research design. The research design was considered appropriate for doing causal studies, which is usually executed so as to give explanation to any reactions or behavior of people to a given phenomenon in the society (Kothari, 2010). In justification for the research design, Cooper \& Schindler, (2010) "noted that explanatory survey design can be conducted to explain hypothesized relationships and also permits the use of inferential statistics in establishing the relationship between dependent 
and independent variables. The design was therefore used to determine the relationship between the variables in the model. The study aimed at investigating effect analysis of Sacco's strategies on member's savings in Sacco's (Nairobi County- Kenya). The study targeted the management of the Sacco's, and clients of savings and credit co-operative societies in Nairobi County-Kenya. Specifically, targeted heads of departments (HOD) namely; Finance and Accounts, Marketing, Human Resource and Credit. From the projected target population which was 242 staff and 11,900 clients/members, constituting target respondents. So as to have a sample size that is representative and with reduced standard errors, the research work employed a technique formulated by Yamane (1967) to determine the sample size for the study. The study targeted heads of departments (HOD) namely; Finance and accounts, Marketing, Human Resource, Credit, Front Office Services Activity (FOSA) and Information Communication Technology (ICT) for all the forty two licensed Deposit taking Sacco's in Nairobi County-Kenya constituting 242 respondents.

In selecting the Sacco clients, out of the approximated 11,900 clients the study employed purposive sampling technique in each of the Sacco visited to select two respondents. Mugenda and Mugenda, (2012), argued that purposive sampling techniques is suitable for homogeneous population and when the researcher want reach the targeted sample quickly as was in this case. Due to practical reasons a population of over 10,000 is too large, too expensive and too time-consuming and in that case a sample of less than $10 \%$ is sufficient for the generalization of the results to the entire population if the sample size in more than 30 elements. In each Sacco office visited at least two respondents who enters the banking hall were selected at random and engaged in the study. A self-managed survey was utilized for information gathering which was essential information. The thought decision of poll was to a great extent be founded on the platform that by and large surveys can be sent to countless and all things considered may help spare the analyst time and different assets. As indicated by Mugenda and Mugenda, (2012) numerous on occasion respondents are likewise increasingly honest when reacting to the survey inferable from the way that their answers are unknown. Information accumulation will be appointed first by looking for consent from Kenyatta University through Academic Supervisor. The scientist at that point leave on information gathering exercise in the field to control the poll. The scientist oversee the surveys face to face and reason to gather them upon fruition.

The information obtained by the research work after fieldwork was edited, coded then keyed in to a computer for processing using the Statistical Package for Social Sciences (SPSS v.21.0). Mugenda and Mugenda (2012) highlighted that, editing of answers/ responses were purposed to eliminate errors made by the researcher or respondents. Accordingly, the collected information will be edited for consistency and completeness before analysis. Descriptive statistics together with inferential statistics were utilized to analyze data generated from respondents. Descriptive statistics refers to, easy applied mathematics strategies, that don't support or falsify a relationship however facilitate within the description of the information. Thus, descriptive statistics can alter the scientist to prepare information in a good method. Inferential statistics are going to be utilized to evaluate whether an association exists within the larger population from that the sample it was drawn from. This aids in creating an applicable generalizations whereby a Pearson correlation co-efficient will be calculated to asses and evaluate the correlation between the dependent variable and independent variable, using the subsequent operate $\mathrm{y} f \mathrm{fn}(\mathrm{X} 1, \mathrm{X} 2$, $\mathrm{X} 3$, and $\varepsilon$ ). From this function, the following multiple regression models has been developed to show the relationship between Sacco's strategies (Loan Policies, Member training, Customer Relationship Management (CRM) strategy, and Member's savings in Sacco's. 


\section{Data Analysis Results}

Correlation analysis was done to show how strongly two variables are related to each other or the degree of association between the two. The findings are shown in Table 1.

Table 1: Members Savings Assessment

\begin{tabular}{|c|c|c|c|c|c|}
\hline & & $\begin{array}{l}\text { Loan } \\
\text { policies }\end{array}$ & $\begin{array}{l}\text { Members } \\
\text { training }\end{array}$ & $\begin{array}{l}\text { Customer } \\
\text { relationship } \\
\text { management } \\
\text { strategy }\end{array}$ & $\begin{array}{l}\text { Members } \\
\text { savings }\end{array}$ \\
\hline \multirow[t]{3}{*}{ Loan policies } & $\begin{array}{l}\text { Pearson } \\
\text { Correlation }\end{array}$ & 1 & $.608^{*}$ & $.143^{*}$ & $.683^{* *}$ \\
\hline & Sig. (2-tailed) & & 000 & .032 & .000 \\
\hline & $\mathrm{N}$ & 224 & 224 & 224 & 224 \\
\hline \multirow[t]{3}{*}{ Members training } & $\begin{array}{l}\text { Pearson } \\
\text { Correlation }\end{array}$ & $.608^{*}$ & 1 & $.697^{* *}$ & $.483^{* * *}$ \\
\hline & Sig. (2-tailed) & .000 & & .000 & .000 \\
\hline & $\mathrm{N}$ & 224 & 224 & 224 & 224 \\
\hline \multirow[t]{3}{*}{$\begin{array}{l}\text { Customer relationship } \\
\text { management strategy }\end{array}$} & $\begin{array}{l}\text { Pearson } \\
\text { Correlation }\end{array}$ & $143^{*}$ & $.697^{* *}$ & 1 & $.290^{* * *}$ \\
\hline & Sig. (2-tailed) & .032 & .000 & & .000 \\
\hline & $\mathrm{N}$ & 224 & 224 & 224 & 224 \\
\hline \multirow[t]{3}{*}{ Members savings } & $\begin{array}{l}\text { Pearson } \\
\text { Correlation }\end{array}$ & $.283^{* *}$ & $.483^{* *}$ & $.290^{* *}$ & 1 \\
\hline & Sig. (2-tailed) & .000 & .000 & .000 & \\
\hline & $\mathrm{N}$ & 224 & 224 & 224 & 224 \\
\hline
\end{tabular}

*. Correlation is significant at the 0.05 level (2-tailed).

**. Correlation is significant at the 0.01 level (2-tailed). N-Sample Size

Source: Research Data (2019)

The Pearson's $r$ for the correlation between loan policies and members training is 0.608 and also loan policies and members savings are is 0.683 which are close to 1 with respective significant value of 0.00 which is less than 0.05 . This shows a strong relationship meaning that changes in one variable are strongly correlated with changes in the second variable. As indicated by Kimani, (2015) inability to rank the application proposes that absence of affirmation on once partner degree somebody would hope to incite a credit that outcomes in individuals' uneasiness and loss of trust. The Pearson's $r$ for the correlation between members training and customer relationship management strategy is 0.697 which is close to 1 with respective significant value of 0.00 which is less than 0.05 . This shows a strong relationship meaning that changes in one variable are strongly correlated with changes in the second variable. According to Kinuthia, (2014) training would, improve cooperation that ensures there exists amongst Sacco members as a feeling of identity, cooperation, mutual concern loyalty and trust.

Regression analysis was carried out to show which among the independent variables were related to dependent variable. The findings are presented in Table 2. 
Table 2: Model Summary

\begin{tabular}{|c|c|c|c|c|c|c|c|c|c|}
\hline & & & & Std. Error & Change St & atistics & & & \\
\hline $\begin{array}{l}\text { Mod } \\
\text { el }\end{array}$ & $\mathrm{R}$ & $\begin{array}{l}\mathrm{R} \\
\text { Square }\end{array}$ & $\begin{array}{l}\text { Adjusted } \\
\text { R Square }\end{array}$ & $\begin{array}{l}\text { of the } \\
\text { Estimate }\end{array}$ & $\begin{array}{l}\mathrm{R} \text { Square } \\
\text { Change }\end{array}$ & $\begin{array}{l}\mathrm{F} \\
\text { Change }\end{array}$ & df1 & df2 & $\begin{array}{l}\text { Sig. F } \\
\text { Change }\end{array}$ \\
\hline 1 & $.529^{\mathrm{a}}$ & .280 & .270 & .721 & .280 & 28.552 & 3 & 220 & .000 \\
\hline
\end{tabular}

a. Predictors: (Constant), Customer relationship management strategy, Loan policies, Members training

Source: Research Data (2019)

The three independent variables (Customer relationship management strategy, Loan policies and Members training) that were studied, explain $27.0 \%$ of the members savings as represented by the adjusted $\mathrm{R}$ square. This therefore means that other factors not studied in this research contribute $73.0 \%$ of members savings. The study therefore recommends that other studies to be carried out to show how other SACCO strategies adopted influences their members savings. Analysis of Variance (ANOVA) was used to determine the linear relationship among the variables under investigation. Using this method, the sum of squares, degrees of freedom (df), mean square, value of $\mathrm{F}$ (calculated) and its significance level was obtained. The results are shown in Table 3.

Table 3: Analysis of Variance

\begin{tabular}{|c|c|c|c|c|c|c|}
\hline \multicolumn{2}{|c|}{ Model } & Sum of Squares & df & Mean Square & $\mathrm{F}$ & Sig. \\
\hline 1 & Regression & 44.567 & 3 & 14.856 & 28.552 & $.000^{\mathrm{a}}$ \\
\hline & Residual & 114.464 & 220 & .520 & & \\
\hline & Total & 159.031 & 223 & & & \\
\hline
\end{tabular}

a. Predictors: (Constant), Customer relationship management strategy, Loan policies, Members training

b. Dependent Variable: Members savings

Source: Research Data (2019)

The significance value is $0.000^{\mathrm{a}}$ which is less that 0.05 thus the model is statistically significance in predicting how customer relationship management strategy, loan policies and members training influenced the SACCO member savings. The F calculated at 5\% level of significance was 28.552. Since F calculated is greater than the F critical ( $p$ value $=14.856$ ), this shows that the overall model was significant.

Table 4: Coefficients

\begin{tabular}{|c|c|c|c|c|c|c|}
\hline \multirow{2}{*}{\multicolumn{2}{|c|}{ Model }} & \multicolumn{2}{|c|}{$\begin{array}{l}\text { Unstandardized } \\
\text { Coefficients }\end{array}$} & \multirow{2}{*}{$\begin{array}{l}\text { Standardized } \\
\text { Coefficients } \\
\text { Beta }\end{array}$} & \multirow[b]{2}{*}{$\mathrm{t}$} & \multirow[b]{2}{*}{ Sig. } \\
\hline & & B & Std. Error & & & \\
\hline \multirow[t]{4}{*}{1} & (Constant) & .237 & .415 & & 7.801 & .000 \\
\hline & Loan policies & .556 & .043 & 2.211 & 3.633 & .000 \\
\hline & Members training & .522 & .081 & 4.518 & 6.459 & .000 \\
\hline & $\begin{array}{l}\text { Customer relationship } \\
\text { management strategy }\end{array}$ & .443 & .112 & 3.102 & 1.271 & .001 \\
\hline
\end{tabular}

a. Dependent Variable: Members savings 
Source: Research Data (2019)

The established regression equation by the study was:

$\mathrm{Y}=0.237+0.556 \mathrm{X}_{1}+0.522 \mathrm{X}_{2}+0.443 \mathrm{X}_{3}$

Where $\quad \mathrm{Y}=$ Members Savings

$\mathrm{X}_{1}=$ Loan policies

$\mathrm{X}_{2}=$ Members training

$\mathrm{X}_{3}=$ Customer relationship management strategy

From the above regression model, holding all the independent variables studied constant, members savings would be $23.7 \%$. In addition, loan policies was found to have a greater influence on members savings at 55.6\% compared to members training (52.2\%) and customer relationship management strategy $(44.3 \%)$. The study established that loan policies had a positive and significant relationship on member savings as indicated by $t$ value $(t=3.633$, p <0.05). Ong'era (2016) study loan repayment reduces losses by matching repayments with income cycles of customers. The study revealed that member training had a positive and significant relationship on member savings as indicated by t value $(t=6.459, p<0.05)$. Anania and Rwekaza (2018) who found that education and training contribute to improved customer care, loan collection, reduced bad debts, better accounting system, improved financial management and time service provision. The study found that customer relationship management strategy had a positive and significant relationship on member savings as indicated by $\mathrm{t}$ value $(\mathrm{t}=1.271, \mathrm{p}<0.05)$. Madziwa (2016) which found that staff is willing to help members with queries and in a responsive manner.

\section{Conclusions}

On loan policies, the study concludes that it is a SACCO policy to appraise loans based on members' savings and ability to repay. However, a member needs to clear any outstanding loan, if any, before applying for another. Basically, loan portfolios have the largest effect on the total risk profile and earnings performance. This earning performance comprises of various factors like interest income, fees, provisions, and other factors of SACCO. On members training, the study concludes that training of members both employees and members leads to increased job satisfaction and morale among employees, motivation, increased efficiencies in processes, resulting in financial gain, increased capacity to adopt new technologies and methods by members, increased innovation in strategies and products and enhanced company image. On customer relationship management strategy, the study concludes that customer relationship management strategy enhances better customer service, CRM systems are useful in identifying potential customers, CRM data ensures effective coordination of marketing campaigns. A CRM system helps in closing faster deals by facilitating quicker and more efficient responses to customer needs and information and helps the SACCO's workforce to know how to deal with each customer depending upon their recorded archives.

\section{Recommendations}

On loan policies, the study recommends that the loan policy should clearly communicate the strategic goals and objectives of the SACCO, as well as define the types of loan exposures acceptable to the institution, loan approval authority, loan limits, loan underwriting criteria, and several other guidelines. The SACCO should have a consistent lending strategy, identifying the types of loans that are permissible and those that are impermissible. Along with identifying the types of loans, the SACCO will and will not underwrite regardless of 
permissibility. On customer relationship management strategy, the study recommends that the SACCO should train members on communications; because the increasing diversity of today's workforce brings a wide variety of languages and customs. Customer service; because increased competition in today's global marketplace makes it critical that employees understand and meet the needs of customers. Diversity; Diversity training usually includes explanation about how people have different perspectives and views, and includes techniques to value diversity and Ethics; Today's society has increasing expectations about corporate social responsibility. Also, today's diverse workforce brings a wide variety of values and morals to the workplace. On customer relationship management strategy, the study recommends that customer relationship strategy should aim at governing how to satisfy customers beyond developing good products and services, help retain existing customers to maximize efficiencies and reduce the cost of acquisition and ensure customer satisfaction and a memorable brand experience.

\section{References}

Anania, P., \& Rwekaza, C. G. (2018). Co-Operative Education and training as a means to improve performance in Co-Operative Societies. Sumerianz Journal of Social

Science, 1(2), $39-50$

Barney, J.B. (2015). "Firm Resources and Sustained Competitive Advantage" Journal of Management 17 (1): 99-120.

C. O.Olando, A. Jagongo, and M. O. Mbewa, (2013) "The Contribution of Sacco Financial Stewardship to Growth of Saccos in Kenya" International Journal of Humanities and Social Science Vol. 3 No. 17; September 2013

C.O.Olando, M O. Mbewa, A. Jagongo, (2013) "The Contribution of Sacco Financial Stewardship to Growth of Sacco's in Kenya" International Journal of Humanities and Social Science Vol. 3 No. 17; September 2013

Champo, S.A. Mwangi; M. \& Oloo (2014) An Analysis of the Socioeconomic Impact of Cooperatives in Africa and their Institutional Context, Nairobi.

Chepkoech, D. (2016). An Assessment Loan Policy and Its Influence on Financial Performance Of Commercial Banks In Eldoret Town (Doctoral Dissertation, Kisii University).

Cooperative Bank of Kenya. (2015) "Co-operative Movement in Kenya”. Nairobi: Cooperate Bank of Kenya

Co-Operative Development Policy (2017) Report "Promoting Co-operative Enterprises for Industrialization" JUNE 2017

D. K. Kariuki, D. Karimi, C. Mutembei, (2017) "Analysis of Factors Influencing Competitive Advantage In Selected Savings And Credit Cooperative Societies In Nairobi North District" The Strategic Journal of Business \& Change Management. ISSN 23129492(Online) 2414-8970(Print).www.strategicjournals.com

Daniel, K. K. (2017). Assessing the Impact of Co-Operative Education/Training on CoOperatives Performance. Journal of Strategy and Performance Management, $5(1), 23-35$

Deji, O. F. (2013). Membership of Co-operative Societies and Adoption Behavior of Women Farmers: Implication for Rural Development. Journal of social science, 10(2), 145 147.

Donald R. Cooper, Pamela S. Schindler, (2010) "Business Research Methods", McGrawHill/Irwin 4th edition.

Evans, (2013), "Managing for Knowledge: HR's Strategic Role”, Butterworth-Heinemann, Amsterdam. 
F. Tumwine, (2015) Savings and Credit Cooperatives (Sacco's) Services' Terms And Members' Economic Development In Rwanda: A Case Study Of Zigama Sacco Ltd. A research project submitted to the Department of Business Administration in the School of Human Resource Development in partial fulfillment of the requirements for the award of the degree of Masters of Business Administration (Strategic Management) of Jomo Kenyatta University of Agriculture and Technology JUNE, 2015

Grant, (1991), 'The resource-based theory of competitive advantage: implications for strategy formulation', California Management Review, vol. 33, no. 3, pp. 114-135.

Grant, (1996), 'Prospering in dynamically-competitive environments: organizational capability as knowledge integration', Organization Science, vol. 7, no. 4, pp. 375387.

Haas, M. R. and Hansen, (2015), 'When using knowledge can hurt performance: The value of organizational capabilities in a management consulting company', Strategic Management Journal, vol. 26, no1, pp. 1-24.

Hamel, G\& Prahalad, (1994), "Competing for the Future", Harvard University Press, Boston.

Josephine C, (2015) Contributions of Savings and Credit Cooperative Society on Improving Rural Livelihood in Makungu ward Iringa, Tanzania. Research Journal (ISSN: 2306367X) 2015 Vol: 4 Issue: 2

Kimani, A.W. (2015). "Inefficiency and ineffectiveness in credit administration. A case study of Chuna Sacco Society ltd”. MBA Thesis, Jomo Kenyatta University of Agriculture and Technology, Juja, Kenya.

Kinuthia, P.M. (2014). "Management of loan default problems in SACCOs in Nairobi province”. MBA Thesis, Jomo Kenyatta University of Agriculture and Technology, Juja, Kenya.

Kioko, M. (2014). Influence of credit Information Sharing on Performance of Deposit Taking SACCOs in Kenya. The strategic Journal of Business and Change Management, 3, 10-21

Kothari, C. R. (2010) Research Methodology; Methods and Techniques (Second Revised Edition 20010 ed.). New Age International Publishers.

KUSCCO, (2016). SACCO star No. 170. Nairobi-Kenya

Madziwa, S. (2016). Influence of Customer Relationship Management on Customer Retention in Sacco Industry (Doctoral dissertation, United States International University-Africa).

Maina, D. T., (2015). “Corporate Finance” Nairobi: Regional Institute of Cooperatives development and Management

Maina, R. G. (2011). The role of cooperative education in the performance of savings and credit cooperative socities: a case of SACCOs in Nyeri District (Doctoral dissertation).

Manyara M.K. (2013) The Development of Cooperative Law and Policy in Kenya, Nairobi.

Manyara M.K. (2013) The Development of Cooperative Law and Policy in Kenya, Nairobi.

Mugenda, A. G. (2012). "Social Science Research; Theory and Principles" Nairobi: Applied Research \& Training Services

Ofei, K.A. (2014). "Retooling credit unions: The case of credit union association of Ghana". IFLIP Research Paper 01-3. Research Paper, International Labor Organization, University of Ghana, Legon.

Ong'era, J. O. (2016). Influence of loan lending policies on financial performance of Commercial Banks Kisii Town (Doctoral dissertation, JOOUST). 
Peteraf, MA\& Bergen, (2013), 'Scanning dynamic competitive landscapes: a market-based and resource-based framework', Strategic Management Journal, vol. 24, no.10, pp. 1027-1041.

Porter, (1996), 'What is Strategy?' Harvard Business Review, vol. 74, no.6, pp. 61-78.

R. N.Osoti, (2014) "Effect of the Growth of Savings and Credit Co-Operative Societies' Front Office Services Activity on Demand for Credit by Members". A research project submitted in partial fulfillment of the requirement of the award of masters of business administration, university of Nairobi

SASRA. (2016). Our Mandate. Accessed at: http://www.sasra.go.ke/aboutus/ourmandate\#.U707kXnlrIU Retrieved on; 17th July 2018

Sinkey, J. F. and Greenwalt, M. B. (2016). "Loan-Loss Experience and Risk Taking Behavior at Large Commercial Banks.” Journal of Financial Services Research, 5, pp.43-59.

Sirmon, DG, Hitt, MA\& Ireland, (2013), 'Managing the firm's resources in order to achieve and maintain a competitive advantage', paper presented at the annual Academy of Management meeting, Seattle.

T. K. Cheruiyot, C. M. Kimeli and S. M. Ogendo, (2012) "Effect of Savings and Credit Cooperative Societies Strategies on Member's Savings Mobilization in Nairobi, Kenya" International Journal of Business and Commerce Vol. 1, No.11: Jul 2012[40-63] (ISSN: 2225-2436)

Teece, DJ, Pisano, G\& Shuen, (2007), 'Dynamic capabilities and strategic management', Strategic Management Journal, vol. 18, no.7, pp. 509-533.

Tiwana, (2012), "The Knowledge Management Toolkit: Orchestrating IT, Strategy, and Knowledge Platforms", 2nd edition, Prentice-Hall, Upper Saddle River

WOCCU -World Council of Credit Unions. (2014). What is a Credit Union? Accessed at: http://www.woccu.org/about/creditunion Retrieved on; 17th July 2018

World Bank, (2013). Financial accountability in Nepal: A country assessment. Washington DC: World Bank Publications

Yamane, Taro. (1967). “Statistics, An Introductory Analysis”, 2nd Ed., New York: Harper and Row.

Zack, (1999), 'Developing a knowledge strategy' , California Management Review, vol. 41, no. 3, pp.125-145.

This is an open-access article published and distributed under the terms and conditions of the $(\mathrm{cc}) \mathrm{EY}$ Creative Commons Attribution 4.0 International License of United States unless otherwise stated. Access, citation and distribution of this article is allowed with full recognition of the authors and the source.

Authors seeking to publish with an International Peer Reviewed Journal should consider https://www.ijcab.org/ by writing to the Editor at editor@ijcab.org. The articles must be quality and meet originality test. 